\title{
OS FALANSTÉRIOS E A CRÍTICA DA SOCIEDADE INDUSTRIAL: REVISITANDO CHARLES FouRIER
}

\author{
José D’Assunção Barros ${ }^{1}$
}

\begin{abstract}
RESUMO
Este artigo busca examinar as idéias de Charles Fourier, escritor do século XIX habitualmente considerado como um "socialista utópico". Uma introdução ao Socialismo Utópico no século XIX, incluindo comentários sobre outros socialistas utópicos como Saint-Simon e Robert Owen, prepara uma análise mais específica dos principais aspectos apresentados por Charles Fourier em sua proposta para um Falanstério. São examinados também aspectos relacionados à crítica social dirigida por Charles Fourier contra a sociedade industrial de sua época.
\end{abstract}

Palavras-chave: Charles Fourier. Socialismo utópico. Falanstério. Utopia.

\section{Phalanstères AND The CRITIQUe OF IndUSTRial SOCIETY: REVISITINg Charles Fourier}

\begin{abstract}
This article seeks to examine the ideas of Charles Fourier, writer of the nineteen century usually regarded as a "utopian socialist". An introduction to the Utopian Socialism in the nineteenth century, including comments on other utopian

\footnotetext{
${ }^{1}$ Professor Doutor da Universidade Federal Rural do Rio de Janeiro, nos cursos de Graduação e Mestrado, e professor colaborador do Programa de Pós-Graduação em História Comparada da Universidade Federal do Rio de Janeiro. Entre suas obras mais recentes destacam-se os livros 0 Campo da História (Petrópolis: Vozes, 2004), o Projeto de Pesquisa em História (Petrópolis: Vozes, 2009). jose.assun@globo.com
} Vozes, 2005), Cidade e História (Petrópolis: Vozes, 2007) e A Construção Social da Cor (Petrópolis:
\end{abstract}


socialists as Saint-Simon and Robert Owen, prepares a more specific analysis of the main issues presented by Fourier in his proposal for a phalanstery. Issues related to social criticism directed by Charles Fourier against industrial society of his time, are also examined.

Keywords: Charles Fourier. Utopian socialism. Phalanstery. Utopia.

\section{O SOCIALISMO UTÓPICO: SEUS IDEALIZADORES E SEU CONTEXTO}

0 chamado "socialismo utópico", designação que já iremos referenciar e discutir em maiores detalhes, constituiu um fenômeno da história das idéias que foi bastante típico da primeira metade do século XIX. De alguma maneira, este se apresenta como uma das muitas respostas ao novo contexto que se anuncia com a sociedade industrial. No início deste novo século, a Europa assistira, já então, ao relativo fracasso da Revolução Francesa em concretizar seus três grandes lemas: "Igualdade, Liberdade, Fraternidade". 0 Industrialismo se alastrara, e de sua espacialidade primordial na Inglaterra estendia-se agora para a França e outras sociedades européias. A burguesia liberal se instalara no poder político, apesar da necessidade de encetar alguns acordos com os poderes monárquicos e de concordar com certas concessões à aristocracia. De outra parte, as cidades assistem a um crescimento bastante significativo, atraindo setores populacionais dos meios rurais, de modo que a população urbana começa a crescer significativamente no interior de um novo quadro tecnológico.

Com tudo isto, a miséria, já desde as primeiras décadas oitocentistas, também passava a se expressar dentro de um novo quadro de intensidades e sociabilidades, de maneira que em breve eclodiriam novos movimentos sociais impulsionados por lideranças que se engajam, mais uma vez, no processo de tentativas de transformação da realidade social e política. Em contrapartida, o Romantismo - por vezes assumindo conotações pessimistas face aos ideais clássicos que não haviam sido realizados pelos movimentos revolucionários do século XVIII - contribui para o novo ambiente mental com uma estética do sonho, do devaneio, da fuga, mas também da desilusão e da loucura. É sob este grande quadro tecnológico, mental e social que se desenham as propostas que ficaram rotuladas pela rubrica do Socialismo Utópico.

Perguntemo-nos, antes de mais nada, pelos homens que veicularam as ideias que podem ser associadas ao Socialismo Utópico. Os chamados "socialistas 
utópicos", na história do pensamento ocidental, são representados principalmente por três nomes mais emblemáticos: Saint-Simon (1760-1825), Charles Fourier (1772-1837) e Robert Owen (1771-1858). Naturalmente que categorizar as idéias, anseios e propostas destes pensadores como "socialismo utópico" é já resultado de uma crítica que seria empreendida mais tarde por Marx e Engels, que propunham designar o socialismo por eles mesmos propugnado como um "socialismo científico". Uma crítica importante aos autores acima, sistematicamente empreendida pelos dois fundadores do marxismo e por quase todos os pensadores que seguiriam a linha do marxismo ocidental, relacionava-se ao fato de que os chamados "socialistas utópicos" procuraram expor detalhadamente os princípios e características de uma sociedade igualitária, por eles idealizada, mas de modo geral sem indicar os meios para alcançá-la. A obra que sistematizou mais claramente estas críticas, de autoria de Friedrich Engels, traz sintomaticamente o título Do Socialismo Utópico ao Socialismo Científico, tendo sido escrita em 1880 em um contexto histórico-político no qual Engels procura contribuir mais efetivamente para a organização do movimento operário, para a constituição de uma agenda de lutas, e para a formalização de uma doutrina socialista que se apresente para a classe trabalhadora com um texto claro e convincente, capaz de expor o projeto socialismo como perfeitamente exeqüível para os movimentos os trabalhadores.

Este contexto, aliás, é particularmente esclarecedor. Isto porque a proposta de Marx e Engels em estabelecer um "socialismo científico" - ou (o que para estes dois autores não era mais do que um desdobramento da mesma idéia) um "socialismo revolucionário" - contrapõe-se não apenas ao fato de que as propostas dos socialistas utópicos idealizam uma sociedade socialista perfeita sem apontar o caminho para atingi-la. Uma pergunta incontornável, cuja resposta poderá distinguir com clareza os utópicos dos fundadores do Materialismo Histórico, seria relativa a quem poderia empreender tais transformações. Procuraremos esclarecer este aspecto em seguida.

Em geral, as utopias que foram relacionadas ao socialismo utópico, da mesma maneira que muitas das antigas utopias literárias que imaginavam sociedades perfeitas, traziam a proposta de serem governadas por uma elite de sábios, ou ao menos deveriam contar com a participação destes homens mais esclarecidos. Saint-Simon, por exemplo, concebe uma sociedade industrial depurada de suas desordens e injustiças, e conduzida consensualmente pelos "produtores" - os operários, empresários, sábios, artistas e banqueiros. Em 
uma de suas primeiras obras, as Cartas de um Habitante de Genebra a seus contemporâneos (1803), ele já há havia proposto que os cientistas tomassem 0 lugar das autoridades religiosas na condução espiritual das sociedades modernas. Mas no ano de sua morte, publicará uma obra intitulada Nova Cristandade (1825), que já se preocupa com a idéia de uma reforma na religiosidade (DESROCHE, 1969)². De todo modo, ainda que a justiça social seja seu horizonte, ainda não é clara a idéia de que fosse necessário descontruir a hierarquização social. Desta maneira, é oportuno ressaltar que nem todos os socialistas utópicos procuram discutir a possibilidade da abolição da sociedade de classes, embora alguns já o façam. Ao mesmo tempo, e este é um traço constante da maior parte dos socialistas utópicos, as sociedades por eles idealizadas pressupõem a boa vontade e participação de todos os que as constituem³.

Existe um ponto crucial para melhor compreendermos a crítica de Marx e Engels aos utópicos, embora não possamos nos deter muito nesta questão, já que nosso objetivo é mais apresentar as idéias de Fourier do que discutir as críticas que lhes foram dirigidas. De um lado, os fundadores do Materialismo Histórico estavam atentos à questão de explicitar quais deveriam ser os agentes da transição para uma nova sociedade. Em primeiro lugar, não deveriam ser indivíduos ou grupos de indivíduos - tal como propunha Fourier, à espera de um capitalista visionário e bem intencionado que lhe financiasse o projeto de construir falanstérios socialistas, ou também Robert Owen, que se erigiu ele mesmo como este industrial que poderia voluntariosamente organizar um novo tipo de unidade de produção de acordo com a sua idealização socialista.

Para Marx e Engels, os agentes de transformação não deveriam ser indivíduos, e sim "classes sociais" inseridas nos "modos de produção", envolvidas em contradições em relação a outras classes que ainda representavam os interesses da sociedade a ser superada. Além disso, os fundadores do Materialismo Histórico se perguntam que classe revolucionária seria esta no contexto mais específico da sociedade industrial. Sua resposta se distancia de Saint-Simon - um socialista

\footnotetext{
${ }^{2}$ Sobre o pensamento utópico de Saint-Simon, ver, PETRE-GRENOUILLEAU, 2001, e MUSSO, 1999.

${ }^{3}$ Assim, por exemplo, Charles Fourier, cujo pensamento utópico analisaremos, acreditava na "bondade natural do ser humano", à maneira do pensamento de Rousseau e outros naturalistas do século XVIII. Seria o sistema de coerções e repressões da sociedade industrial - que Fourier chamará em tom depreciativo de "Civilização - o que terminava por introduzir as desordens morais, convertendo os instintos naturalmente bons em tendências agressivas e degeneradas.
} 
utópico que já raciocina em termos de classes, mas que acredita que os agentes da transformação seriam os industriais empreendedores. De fato, para Marx e Engels, a única saída possível para uma nova sociedade estaria a cargo dos proletários. Para entender e esclarecer porque esta classe deveria ser o agente de transformação Marx percebe a necessidade de elaborar uma crítica da Economia Política. Para desenvolver uma ciência revolucionária, e concomitantemente promover o desenvolvimento de um socialismo científico, seria preciso entender o próprio capitalismo em funcionamento - seu regime de propriedade privada e trabalho assalariado, o papel da mercadoria e do valor, os modos como neste sistema se dá a alienação humana, e, sobretudo, as maneiras como este mesmo sistema produz as contradições que o farão ser destruído. A crítica deixa aqui de ser moral - mera denúncia dos valores deteriorados da civilização industrial e de suas formas de opressão, como ocorre com os filósofos e os socialistas anteriores - e passa a agregar uma sistemática análise de fundo econômico. Compreender o cerne do funcionamento da sociedade capitalista e inserir esta compreensão em uma agenda de lutas, a cargo de uma classe social específica que seria a dos proletários, deveriam ser ações gêmeas prontas a convergir para a eliminação da relação social capitalista como um todo.

Compreendida esta íntima relação de um novo modo de examinar a sociedade industrial com as críticas viscerais que são elaboradas por Marx e Engels contra os "utópicos", podemos retornar ao nosso objetivo, que será o de apresentar o pensamento de Fourier e, lateralmente, de outros daqueles que foram chamados por Engels de "socialistas utópicos", expressão que adotaremos a partir daqui para facilitar a exposição. Se os socialistas utópicos avançam pouco na concretização de meios para atingir efetivamente uma sociedade sem maiores desigualdades, e se de modo geral passam ao largo da crítica econômica da sociedade industrial, não há como negar, contudo, que eles avançaram significativamente na crítica social e política de sua época ao denunciar uma sociedade produtora de misérias, contra o pano de fundo do otimismo de muitas das cabeças pensantes da época diante de

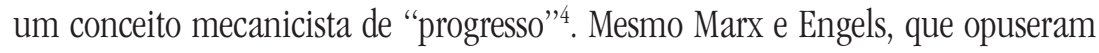
o "socialismo científico" ao "socialismo utópico", não deixaram de reconhecer a importância da crítica social levada adiante por um Charles Fourier, que teria

\footnotetext{
${ }^{4}$ Walter Benjamin, em suas Teses sobre o Conceito de História (1940), irá criticar visceralmente este conceito mecanicista de progresso, do qual não estavam isentos, inclusive, muitos dos materialistas históricos. Fourier, aliás, é admirado por Benjamin, e mencionado na tese n. 11 (BENJAMIN, 2008, p. 228).
} 
exposto a miséria moral e as desordens trazidas por uma sociedade industrial que não se fizera acompanhar de justiça social, de modo que o Manifesto Comunista (1848) traz mesmo reminiscências da retórica e da crítica social encaminhada por este filósofo francês em algumas de suas obras.

\section{UTOPIAS: SONHOS OU ANTEVISÕES?}

Conforme vimos atrás, uma das mais importantes críticas dos pensadores e líderes de movimentos sociais aos chamados "socialistas utópicos", já desde o século XIX, refere-se à impossibilidade de realizar suas utopias através de um caminho definido de lutas e realizações concretas. 0 sonho de utópicos como Fourier repousava em um anseio de que os próprios industriais burgueses e outros homens poderosos se comoveriam diante de seus projetos, terminando por concordar em financiar, de alguma maneira, seus empreendimentos. Somente Robert Owen, um industrial de recursos, pôde ultrapassar as páginas da própria literatura utópica por ele produzida (1820) e partir em sua própria vida para uma prática direcionada à concretização de um novo mundo social, pois neste caso ele mesmo era 0 industrial a ser conclamado para o projeto igualitário. 0 fracasso de seu projeto, contudo, expressa talvez as dificuldades de entender que seria impossível superar o padrão mais habitual das sociedades industriais sem avançar na própria crítica de seu funcionamento. Charles Fourier, por seu turno, terminou por esperar a vida inteira, sem sucesso, que algum burguês rico se interessasse pelo seu projeto de construir estas unidades sociais que chamou de Falanstérios. É a sua idealização de uma sociedade igualitária e equilibrada que descreveremos a seguir.

Desde já, é interessante lembrar que Fourier nunca se viu como um mero idealizador a sonhar uma utopia. Possivelmente estranharia a designação de "utopista"se soubesse que um dia estaria inscrito nas galerias da História das Idéias sob este rótulo, e ao lado de outros pensadores sociais como Saint-Simon e Robert Owen, uma vez que ele mesmo não deixara de encaminhar suas próprias críticas a estes dois idealistas, e a outras "utopias" como a da República de Platão (2004). Em uma palavra, Fourier via o seu próprio projeto como perfeitamente realizável, e dirigia uma nota de depreciação às utopias ou às idealizações imaginárias de seus predecessores, bem como aos projetos utópicos que foram seus contemporâneos.

Cuidemos de pontuar, inicialmente, a especificidade do contexto históricosocial sobre a qual se estabelecem a obra e os projetos utópicos de Fourier. Já escrevendo de um mundo relativamente avançado em termos industriais, e que assistira aos decepcionantes recuos da Revolução Francesa no que se refere aos seus 
mais fundamentais anseios pela justiça social, Charles Fourier (1772-1837) pretende erigir o seu sonho de uma sociedade justa e igualitarista com base na complacência de 'capitalistas esclarecidos' sintonizados com as idéias liberais. Desta maneira, Fourier descartará a revolução violenta como meio de concretizar o novo mundo social, para ele nada mais do que uma nova etapa no desenvolvimento da humanidade, e dirigirá todas as suas apostas para a possibilidade de convencer ricos e poderosos a se juntarem a ele no seu sonho socialista.

Em que pese a dimensão de devaneio, sonho e especulação que hoje nos parecem pautar a utopia proposta por Fourier, a verdade é que este francês nascido em Besançon via a sociedade por ele idealizada como um empreendimento concreto a ser realizado. 0 grande fundador desta utopia que seria uma sociedade formada por "falanstérios", neste caso, deveria ser ele mesmo - de modo que aqui não mais se tratava de mero esforço de imaginação que remetia a um fundador imaginário, tal como havia ocorrido com diversas das utopias dos séculos anteriores, a exemplo da Utopia de Thomas Morus (1478-1535) ou da Nova Atlântida de Francis Bacon (1561-1626)5. Em contraste com estas utopias dos períodos renascentista e clássico, a utopia de Fourier anunciava finalmente um fundador concreto, embora um fundador histórico que, não obstante, não logrou obter qualquer sucesso efetivo na implantação do seu projeto. Assim, o Fourier que pretendia se tornar o fundador efetivo de uma nova Sociedade acaba se transformando em mais um fundador imaginário como os outros - um personagem engolido pela sua própria utopia não realizada. A nova Era por ele anunciada não se realiza sequer como um projeto mal sucedido, tal como ocorre com as colônias fundadas por Robert Owen na Inglaterra e Estados Unidos ${ }^{6}$.

\footnotetext{
${ }^{5}$ A Utopia, do humanista Thomas Morus, foi escrita por 1516, e seria o nome de uma sociedade imaginada e descrita por este escritor e político inglês neste livro que, adicionalmente, daria origem ao termo "utopia". Alguns analistas avaliam a obra como uma idealização de uma sociedade perfeita, e outros a consideram como uma maneira de satirizar ou evidenciar as deficiências das sociedades de sua própria época. De todo modo, o artifício utilizado por Morus é a realização literária, e o personagem de seu livro chega a uma sociedade que já existe na realidade literária da obra. Assim como a utopia de Morus, também a Nova Atlântida (1627) de Francis Bacon (2008), é proposta como uma sociedade perfeita governada por sábios, e se apresenta como criação literária.

${ }^{6} 0$ industrial Robert Owen (1771-1858) tentou ele mesmo implantar a sua sociedade reformada - a colônia socialista New Harmony - investindo seus próprios recursos em colônias cooperativas onde a propriedade privada seria extinta. Ele mesmo já vinha obtendo algum sucesso em sua atividade industrial - organizando suas fábricas de maneira surpreendentemente humana e com grande justiça social, sem que isto prejudicasse o progresso capitalista de seus empreendimentos. Contudo, as tentativas de concretização do seu projeto realmente igualitarista fracassaram, em parte porque este projeto sofreu muitas resistências da aristocracia inglesa de sua época.
} 
Outro aspecto importante a se levar em consideração, antes de adentrarmos 0 modelo utópico elaborado por Fourier, é o fato de que este autor considerava a própria realidade em que vivia como um "mundo ao avesso", ou como uma sociedade enlouquecida e desajustada, uma realidade social atravessada por desordens, de modo que a sua proposta era precisamente a de endireitar a realidade. A desmedida desigualdade social, o casamento monogâmico, o trabalho imposto como obrigação, a tendência à especialização - todos estes aspectos foram vistos por Fourier como instâncias absurdas que ao mesmo tempo expressavam e perpetuavam uma sociedade doente, uma espécie de sonambulismo social que impunha aos seres humanos um padrão de vida bem inferior àquele do qual poderiam usufruir. A miséria social seria, ela mesma, "a mais escandalosa das desordens". 0 capitalismo - e a sociedade industrial - corresponderia à "desordem generalizada".

Vejamos, em seguida, o modelo de sociedade perfeita que Fourier idealiza para contrapor a esta "sociedade de desordens" que coincide com a "Civilização", esta fase da humanidade que, de acordo com o pensador francês, corresponderia ao estágio mais degradado de uma história humana que decaíra através cinco vibrações negativas desde que abandonara o "Éden Primitivo", conforme nos relatam as especulações que começam a já ser desenvolvidas em sua obra Os Quatro Movimentos (1808) ${ }^{7}$.

\section{Os Falanstérios de Fourier}

\section{E A VIDA EM HARMONIA}

As Falanges propostas por Fourier seriam correspondentes a pequenas unidades sociais com populações de cerca de 1500 habitantes $^{8}$, e cada uma possuiria um edifício comum chamado Falanstério no qual todos viveriam harmoniosamente?

${ }^{7}$ Conforme Fourier, a humanidade teria conhecido cinco grandes fases, cujas mudanças teriam sido regidas ou por alterações de vibrações - ascendentes (harmônicas) ou descendentes (caóticas) - de modo que, com isto, estes seriam os grandes períodos da história da humanidade: Éden primitivo, Selvageria, Patriarcado, Barbárie, Civilização. 0 termo "civilização", contudo, não deve nos enganar: para Fourier esse estágio constituiria uma grande desordem, apenas disfarçada pela falsa idéia de progresso.

${ }^{8}$ Fourier é na verdade bastante preciso, estabelecendo a quantidade ideal de 1620 homens e mulheres que deveriam corresponder aos 810 tipos de caráter nos quais ele julgava serem repartidas todas as possibilidades para a alma humana.

${ }^{9} \mathrm{Na}$ verdade, em uma obra chamada A Teoria dos quatro movimentos, Fourier havia chegado à curiosa conclusão de que o falanstério deveria abrigar uma população de 1620 pessoas (810 de cada sexo). Fourier chegou ao seu número de 1620 a partir da teoria que desenvolvera 
Apesar de um cálculo relativo ao emparelhamento numérico de homens e mulheres, a idéia era que a vida no Falanstério levaria espontaneamente à dissolução de formações sociais rudimentares como a célula familiar monogâmica e restrita. Para isto, o falanstério teria muitos espaços de socialização, inclusive as refeições, que seriam coletivas. Fourier era um crítico visceral do Casamento, e acreditava que se este fosse derrubado tudo o mais se ajeitaria espontaneamente, conduzindo a uma sociedade realmente livre. A ruptura natural com a monogamia era um dos itens previstos com o desenvolvimento dos falanstérios.

0 comportamento tendente à multiplicação de contatos amorosos era chamado por Fourier de "angélico". Ele apregoava um comportamento humano francamente hedonista, no qual todos buscassem o máximo de prazer (o que também pode ser visto na Utopia de Thomas Morus, 1997). Também antecipava em quase cem anos, com a sua utopia polígama, algumas das idéias de Wilhelm Reich (1994), que via na camisa-de-força monogâmica a base de alguns dos males da Sociedade, entre os quais a monotonia e a formação de uma agressividade recalcada ${ }^{10}$, desdobramentos diretos desta situação matrimonial que Fourier considerava como uma espécie de "prostituição hipócrita e legal" que terminava depois de alguns anos por gerar doenças e ressentimentos, ou então uma cascata de infidelidades desenfreadas, multiplicando estas figuras deprimentes dos maridos e mulheres traídos que, julgando-se proprietários do outro, acabavam por se verem afrontados precisamente naquilo que foram educados a conceber como último reduto de sua honra $^{11}$.

Para Fourier, aliás, o livre acesso aos prazeres eliminaria tanto as tendências ao excesso destemperado, como permitiria que os homens descobrissem realmente 0 Prazer, alimentando-se com mais gosto e amando com uma serena plenitude sexual.

dos Quatro Movimentos, segundo a qual os seres humanos seriam impulsionados por treze paixões especificadas. A população do inicial do Falanstério devia ser calculada de modo que todos na comunidade tivessem a oportunidade de encontrar outros com características complementares à sua.

${ }^{10}$ Fourier, ele mesmo, teria se conservado celibatário em sua vida pessoal; Máxime Leroy (1948), que o pinta com cores contraditórias, desenha a sua figura pessoal como a de um "velho e teimoso celibatário".

${ }^{11}$ Fourier, que apresentava uma espécie de mania por números e detalhamentos, descreve, na Teoria dos Quatro Movimentos (1808), 64 categorias de "cornos", entre as quais o "corno potencial" e o "corno póstumo"! Depois amplia a sua pesquisa e, já no Tratado de Associação Doméstica e Agrícola (1822), consegue ampliar a sua lista para 144 tipos. Sobre isto, ver Petitifils, 1977, p. 92. 
Um segundo desdobramento dos casamentos monogâmicos exigidos pela "Civilização", de acordo com Fourier, seria a tendência a se formarem famílias nucleares inteiramente fechadas sobre si mesmas, transformando-se em células egoístas e anti-sociais que se colocavam cada qual em guarda, ou mesmo em guerra, contra todas as outras famílias, cada qual reproduzindo, de sua parte, o modelo da pequena célula egoísta e fechada sobre si mesma. 0 casamento monogâmico, desta forma, inibia a possibilidade da comunhão universal, do amor de cada um voltado para todos, da grande fraternidade universal que um dia havia sido prometida pela Revolução Francesa, e antes disto pela Bíblia.

A grande contribuição trazida por Fourier em sua crítica contra o casamento monogâmico, contudo, foi a sua percepção de que, na "Civilização", a mulher terminava sempre por se transformar na contraparte inferior, escravizada pelo marido e tratada como mera mercadoria sob seus cuidados ${ }^{12}$. 0 gênero masculino, no matrimônio monogâmico, toma o lugar de um "déspota familiar", oprimindo simultaneamente a mulher e a criança. Já nos falanstérios as crianças deveriam ser educadas mais espontaneamente, com um mínimo de interferência dos adultos. Fourier flerta com o Anarquismo, mas carregando na utopia. Acreditava que um setor específico do conjunto de crianças tenderia a criar brincadeiras em torno de temas como o cuidado dos jardins e a limpeza das dependências comuns do falanstério, de modo que este trabalho seria feito automaticamente como atividade lúdica. Para além disto, o Trabalho dos adultos também seria alegre, com variedade de atividades, o que evitaria o tédio e a fadiga ${ }^{13}$.

No falanstério, não haveria seres humanos improdutivos - tal como existiam no estado de "Civilização" que o seu sistema pretendia superar. Segundo

${ }^{12}$ Esta percepção coloca Fourier mais uma vez como um homem à frente de seu tempo, considerando-se que, ao lado de alguns poucos nomes que refletiram mais atentamente sobre a condição da mulher no século XIX, o filósofo francês certamente desenvolveu uma das mais fortes críticas de sua época à desigualdade de gêneros. Ainda seria preciso um século para que aforassem efetivamente as reflexões feministas, à parte o pioneirismo de homens como Fourier e de mulheres como Flora Tristan (1803-1844). Em contraposição à noção tecnológica de progresso, Fourier chega mesmo a formular a idéia de que seria possível medir o grau de "progresso social" de uma nação pelo grau de emancipação feminina.

${ }^{13}$ A variação de atividades no exercício do Trabalho (durando cada tipo de atividades no máximo duas horas) evitaria que os homens reprimissem uma das treze "paixões" fundamentais do ser humano, segundo Fourier: a paixão de borboleta. A "paixão de borboleta" era 0 eterno desejo de variedade (de passar de uma para outra flor) que seria um aspecto inerente a uma natureza humana saudável. Desta forma, o Falanstério não seria um mundo de especialistas dedicados exclusivamente às suas profissões. 
Fourier, a improdutividade abarcava cerca de 2/3 dos seres humanos, entre profissões desnecessárias e improdutivas, fora os ociosos de várias espécies e as mulheres mantidas em reclusão doméstica. Ao mesmo tempo, o Trabalho deveria sempre ser constituído por uma dimensão de prazer e por um aspecto lúdico, o que expressava, aliás, a aversão de Fourier ao fato de que a maior parte dos seres humanos realizava um trabalho que não apreciava efetivamente. Em Fourier, veremos que existem referências pessoais e autobiográficas nas diversas das situações que são apontadas como deturpações a serem corrigidas. Em sua juventude, Fourier havia sido obrigado a trabalhar, contra a sua vontade, como balconista ligado ao Comércio - e agora reagia contra isto ao elaborar um modelo utópico que excluía dos quadros sociais o trabalho exercido sem prazer e vocação.

0 pacifismo de Fourier, sua rejeição a qualquer forma de violência, também remontava a arbitrariedades por ele sofridas, no caso por ocasião do Terror na Revolução Francesa. No Falanstério, não poderia haver lugar para a violência, ou para qualquer tipo de atividade compulsória. Esse impulso de corrigir a vida através da imaginação, de reagir através de fantasias utópicas contra aspectos por ele sofridos em sua vida cotidiana ou em algum momento de sua vida, será uma marca presente nos escritos de Fourier que não cansarão de ser anotados pelos seus biógrafos e analistas.

Outro aspecto importante dos Falanstérios era sua dimensão hedônica. 0 modelo de felicidade proposto por Fourier é francamente voltado para a busca e satisfação dos prazeres, e as paixões não deveriam ser evitadas, mas sim diversificadas e ampliadas como uma das condições para se atingir a "verdadeira felicidade". Com sua obsessiva tendência à sistematização, Fourier procura contabilizar e descrever desde as paixões correspondentes aos sentidos (visão, olfato, etc) até aquelas "afetivas" (amor, amizade, ambição, e outras). Além dessas, chega a descrever três paixões que não existiriam no estado de Civilização, por serem inibidas por este: as paixões "cabalista ou dissidente", a "borboleta ou alternante", e a "composta ou engrenante". A "paixão borboleta", por exemplo, corresponderia ao gosto pela diversificação, ao desejo de variar na atuação entre todos os domínios, e seria uma paixão inibida neste estado de Civilização que impõe a especialização e a divisão de trabalho. Podemos nos impressionar mais uma vez com a capacidade visionária de Fourier, que antecipa uma crítica ao especialismo que só se torna mais intensa na segunda metade do século $\mathrm{XX}^{14}$.

${ }^{14}$ Encontraremos também em Marx uma preocupação notável com a não-realização do homem no trabalho, particularmente nos trechos dos Manuscritos Econômico-Filosóficos 
Por fim, para concluir sua minuciosa descrição das paixões, Fourier descreve uma paixão só poderia urgir após superado o estado deficiente de Civilização: 0 "uniteísmo", que seria o contrário do "egoísmo"15.

Em termos de busca de maior Igualdade e Justiça Social, a proposta de Fourier era sinceramente dedicada à possibilidade de minimizar a Desigualdade, mas ele admitia que haveria diferenças entre os habitantes do Falanstério. 0 dinheiro e a propriedade privada, por exemplo, não seriam suprimidos - apesar de que, na vida "societária" e saudável do Falanstério, purificada dos padrões de egoísmo e individualismo que até então haviam caracterizado a sociedade dita "civilizada", nem o dinheiro nem a Propriedade teriam quaisquer dos efeitos danosos do sistema de opressão econômica. Por outro lado, como modelo de redistribuição da riqueza, previa-se que esta seria orientada de acordo com a qualidade do Trabalho produzido por cada um - o que justificaria as diferenças em termos justos. Bem estabelecido, não seria uma remuneração privilegiando propriamente tipos diferentes de trabalho, mas sim a eficiência e o benefício real que os grupos profissionais estivessem produzindo para a Comunidade. Quanto menos doentes tivesse um falanstério, mais os médicos deste falanstério seriam bem remunerados; quanto menos problemas estruturais ou de manutenção afligissem o Edifício, mais ganhariam os engenheiros e técnicos; afinal, tais índices indicariam que eles estavam fazendo melhor o seu trabalho (a lógica, desta maneira, é inversa à da Civilização, na qual os modos de aferição do mérito, quando existem, relacionam-se apenas às quantidades de trabalho consideradas mecanicamente). Da mesma forma, quanto mais deliciosa e nutritiva fosse a alimentação, mais ganhariam os cozinheiros ou os que naquele mês tivessem se dedicado às atividades alimentícias. Cada grupo funcional - ou cada "série", segundo a terminologia dos falanstérios - faria um significativo esforço coletivo para elevar o padrão dos resultados de seu trabalho e, desta forma, seus próprios ganhos.

(1844) em que Marx discute a alienação do trabalho no Capitalismo. Também podemos lembrar uma célebre passagem de Marx e Engels em A Ideologia Alemã (1975, p. 41): "Na sociedade comunista, na qual cada indivíduo pode aperfeiçoar-se no campo que lhe aprouver, não tendo por isso uma esfera de atividade exclusiva, é a sociedade que regula a produção geral e me possibilita fazer hoje uma coisa, amanhã outra, caçar de manhã, pescar à tarde, pastorear a noite, fazer crítica depois da refeição, e tudo isto a meu bel-prazer, sem por isso me tornar exclusivamente caçador, pescador ou crítico".

${ }^{15}$ A sistematização proposta por Fourier não termina aqui. Uma vez encerrada a descrição das paixões fundamentais, ele começa a pensar a possibilidade das suas combinações como traços que seriam característicos dos vários tipos humanos, e chega à identificação de 810 tipos de caráter. 
Por outro lado, tal como já foi dito, um cidadão do falanstério não precisaria estar aprisionado em uma única profissão, sendo previsível que a maioria se dedicaria variadamente ao exercício de várias funções. Aqui, retorna a referência ao desejo natural de variedade, ao qual já nos referimos no momento em que mencionamos o sistema de categorias de "paixões" sistematizado por Fourier. Na linguagem de Fourier, esse desejo de variedade corresponde à paixão do "borboletear", uma paixão reprimida no estado atrasado da "Civilização".

Digno de nota é o extremo detalhismo com que Fourier planejava a instalação do seu Falanstério. Concebeu desde a sua Arquitetura até a indumentária a ser utilizada pelos seus habitantes. As roupas teriam botões nas costas, pois assim os seres-humanos precisariam sempre uns dos outros para abotoá-los e desabotoálos, o que impediria o estabelecimento dos padrões individualistas e egoístas que tanto caracterizavam a sociedade "civilizada" do seu tempo. Os calçados por ele imaginados seriam resistentes e práticos, e não inutilmente sofisticados e voltados para uma estética em permanente mutação. Imaginou uma centena de expedientes para evitar desperdícios e gastos desnecessários.

Há uma descrição pormenorizada do Falanstério no que se refere à sua arquitetura possível. 0 Falanstério seria um palácio de muitas alas - um verdadeiro "turbilhão" paradisíaco, para nos colocarmos diante da etimologia buscada por esta designação - e compreenderia galerias envidraçadas, pátios internos, jardins, galpões, salas comunais, oficinas, hospedarias, áreas lúdicas que incluiriam um Teatro, e até mesmo uma Igreja, uma vez que Fourier atrela seu projeto a um novo tipo de Cristianismo pronto a asseverar que a satisfação de todas as paixões seria recomendável, já que "todas viriam de Deus"16. As alas do Falanstério também teriam apartamentos de preços diferentes (20 tipos de preço), mas o número máximo de peças que poderiam ser possuídas por um habitante do Falanstério seria três. Deste modo, ainda que não se mostre a ambição de realizar a Igualdade plena, existiriam medidas evitando a concentração de propriedade, da mesma forma que a economia do Falanstério - essencialmente baseada na agricultura, mas também incluindo manufaturas - asseguraria a todos o uso das áreas de cultivo e de outros tipos de trabalhos ${ }^{17}$.

\footnotetext{
${ }^{16} \mathrm{~A}$ associação entre hedonismo radical e religiosidade cristã, em Fourier, permite lembrar algumas das seitas protestantes radicais da Inglaterra no século XVII, estudadas por Christopher Hill no seu célebre livro O Mundo de Ponta-Cabeça (1987).

${ }^{17} 0$ modelo econômico de Fourier, ao priorizar a agricultura e mesmo inviabilizar a possibilidade da grande-indústria, remete ainda à retomada de um mundo pré-capitalista, tal
} 
ACultura, resta dizer, adquiriria um lugar central nesta nova era da Harmonia, que substituiria a degradada "Civilização". Cada Falanstério só poderia se realizar plenamente se fosse bem sucedido em transformar cada um de seus habitantes em um artista sensível tanto às diversas formas de sociabilidade como à estética e à ecologia do novo mundo. Por isso, cada habitante de um falanstério deveria buscar também 0 seu treinamento como ator ou praticante de alguma arte. 0 Teatro, em especial, por realizar a fusão entre Arte e Sociabilidade, encontraria seu lugar especial neste mundo no qual cada um se faria ator, e no qual uma grande troca de espetáculos de Teatro, Música e Dança poderia criar uma dinâmica associativa e lúdica entre as falanges que habitassem os diversos falanstérios espalhados no planeta - sim, pois a certa altura, o sonho utópico de Fourier já encontra um dimensionamento planetário. A rede planetária de falanstérios nos apresenta, com os sonhos de Fourier, não apenas um novo mundo industrial e agrícola, como também um novo mundo artístico, e, sobretudo, um novo mundo amoroso - um mundo no qual estaria superada a "legalidade prostituída" do vil casamento monogâmico, em favor de um mundo de livres orgias no qual surgiria uma "prostituição santa", pronta a ministrar cursos de amor e a oferecer a todos este que é o mais lúdico dos trabalhos que requerem a dedicada especialização da arte erótica, da mesma forma que surgiriam verdadeiras "hordas de cavalaria amorosa" secundadas por trupes de trovadores e sedutoras quadrilhas de vestais e bacantes ${ }^{18}$. Por outro lado, neste novo mundo amoroso no qual todos os desejos e inclinações sensuais podem ser satisfeitas à vontade, mas também sem obrigação, haveria também lugar para emergir o puro amor - 0 "amor celadônio" - que consistiria em uma refinada variedade deste tipo de amor que hoje chamamos de "amor platônico".

Há um devaneio final, de fundo místico, na Harmonia idealizada por Fourier. Com a transformação do mundo, ansiosamente aguardada por Deus - que do alto de sua sabedoria eterna estaria apenas esperando que os homens completassem o seu trabalho - a própria natureza se modificaria, e se tornaria parceira da humanidade, reintroduzindo aquele harmonioso mundo das fábulas no qual os homens e os animais cooperavam uns com os outros, no qual as baleias (ou anti-baleias) puxavam alegremente as embarcações e os anti-leões substituíam mais eficazmente

como utopias anteriores e alguns modelos imaginários típicos dos setores do Romantismo que foram mais pessimistas e críticos em relação ao advento da Sociedade Industrial.

${ }^{18}$ A economia da Harmonia, a nova era dos falanstérios, não se refere apenas a questões materiais a serem resolvidas na "bolsa de valores"; um lugar mais importante é destinado à "bolsa das inclinações amorosas". 
os cavalos. Para acompanhar esta nova sociedade, uma nova natureza substituiria 0 mar salgado por um mais aprazível oceano de limonada. E mesmo o homem, já mais alto e com uma longevidade média de 144 anos, poderia finalmente modificar o seu próprio corpo, nascendo-lhe oportunamente um terceiro braço - um "arquibraço" que completaria a eficácia de seus movimentos corporais.

Entre antecipações que se mostraram visionárias e devaneios que se revelaram dotados de forte conteúdo criativo para artistas posteriores, como os da falange dos surrealistas, no século XX, estabelecia-se, ao menos na mente de Fourier uma nova Era. Estas foram as "centelhas de esperança" lançadas por este filósofo e economista francês no seio da sociedade industrial nascente, por ela e contra ela. Restava realizar estes devaneios que se apresentaram com tal intensidade ao seu autor que the pareciam ser indiscutivelmente a verdadeira realidade, que apenas estivera oculta à espera de ser um dia anunciada por este "profeta posterior" a Cristo que era ele mesmo ${ }^{19}$. Todavia, seria particularmente significativo o sintomático fato de que Fourier pretendia que liberais progressistas financiassem o seu projeto de implantação efetiva do Falanstério. Escreveu cerca de quatro mil cartas a pessoas poderosas, ricas ou influentes, na esperança de obter apoio para o seu projeto. Também colocou anúncios em jornais mostrando-lhes que poderiam obter grandes lucros caso investissem nos falanstérios, que também seriam produtivos. Assim, aguardava todos os dias, à mesma hora, a chegada do mecenas liberal que financiaria o seu projeto de reforma social. Esse capitalista progressista interessado em utopias sociais não apareceu nunca. Ao final de sua vida, já idoso, Fourier já admitia que talvez a história da humanidade tivesse de conhecer algumas etapas intermediárias, antes de ser possível o "salto" da Civilização para a Harmonia. Neste sentido, Fourier torna-se o exemplo clássico do socialista utópico que idealiza uma comunidade perfeita, mas não consegue encontrar meios efetivos de produzir o seu aparecimento, ou mesmo de contribuir para transformações da sociedade já existente com vistas a uma gradual aproximação do modelo social pretendido.

Eis enfim, o projeto utópico de Fourier - um mundo produzido por uma imaginação ao mesmo tempo visionária e excêntrica, já que adaptado também às próprias necessidades pessoais de Fourier. Esse mundo fantástico, previsto nos seus mínimos detalhes, mesmo que nem sempre realizáveis, não deixou de impressionar pensadores, artistas e políticos posteriores. Os surrealistas veneraram

${ }^{19}$ Era como profeta de um novo mundo, mas na verdade como aquele que iria realizar plenamente este paraíso terreal povoado de falanstérios, que Fourier via a si mesmo. Se João Batista fora o "profeta anterior" a Cristo, ele mesmo seria o "profeta posterior". 
a sua imaginação plástica e fabulista; Walter Benjamin (1940), um não menos visionário pensador ligado ao Materialismo Histórico, o resgata como um modelo de esperança revolucionária nas suas célebres Teses sobre o Conceito de História. A sofisticação de sua imaginação e construção literária atraiu analistas do porte do semiólogo Roland Barthes (1979), ou do filósofo e historiador Leandro Konder (1998), no Brasil. 0 Falanstério de Fourier nos traz um mundo de esperanças e de audácias imaginárias, mas também brota da própria vida concreta de Fourier, tensionado contra a sua própria época: sua indisposição frente às correntes de ar o leva a envidraçar as alas de seu Falanstério; sua traumática experiência de ser coagido a trabalhar em um ofício para o qual não tinha vocação o leva a atribuir um lugar especial, em seu sistema, para a liberdade total na escolha individual do trabalho. De igual maneira, seu inquieto interesse por todas as coisas o leva a edificar o "borboletear" como uma paixão natural que vem sendo reprimida no medíocre mundo da Civilização, mas que no Falanstério encontraria a liberação definitiva. Sua ligeira aversão à agitação infantil o conduz a encontrar um lugar ao mesmo tempo lúdico e útil para a energia das crianças mais agitadas, que fariam do serviço de colher o lixo uma grande brincadeira. Cada talento, até o menos precioso na sua aparência, encontraria no Falanstério de Fourier o seu lugar de destaque, a sua contribuição para o equilíbrio desta nova era da humanidade que deveria, daí em diante, ser chamada de "Harmonia".

\section{REFERENCIAS}

BACON, Francis. A Nova Atlântida. Lisboa: Ed. 70, 2008.

BARTHES, Roland. Sade, Fourier, Loiola. Lisboa: Ed. 70, 1979.

BENJAMIN, Walter. Teses sobre o conceito o História. In:__. Walter

Benjamin: obras escolhidas - magia e técnica; arte e política. São Paulo: Brasiliense, 2008. p. 222-231.

DESROCHE, Henri. Saint-Simon: Le nouveau christianisme et les Écrits sur la religion. Paris: Seuil, 1969.

ENGELS, Friedrich. Do socialismo utópico ao socialismo científico. São Paulo: Fugor, 1962.

FOURIER, Charles. Theorie des quatre mouvements. In: Ouevres completes. Paris: Antropos, 1966-1968. 
Traité de l'association domestique agricole. In: Ouevres Completes. Paris: Antropos, 1966-1968. . Le nouveau monde industriel et societaire. In: Ouevres Completes. Paris: Antropos, 1966-1968.

. La fausse industrie, morcelée, mensogère et l'antidote, ç'industrie naturelle, combinée, attrayante, véridique, donnant quadruple production. In: . Ouevres Completes. Paris: Antropos, 1966-1968.

SAMPAIO, Ernesto (Org.). Charles Fourier. São Paulo: Salamandra, 1996.

HILL, Christopher. O mundo de ponta-cabeça. São Paulo: Companhia das Letras, 1987.

KONDER, Leandro. Fourier: o socialismo do prazer. Rio de Janeiro: Civilização Brasileira, 1998.

LEROY, Maxime. Les précurseurs français du socialisme: de Condorcet à Proudhon. Paris: Editions du Temps présent, 1948.

MARX, Karl. Manuscritos econômico-filosóficos e outros textos escolhidos. São Paulo: Nova Cultural, 1991.

MARX, Karl; ENGELS, Friedrich. Manifesto do partido comunista. Petrópolis: Vozes, 1988. . A ideologia alemã. Lisboa: Presença, 1976.

MORTON, Arthur Leslie. The life and ideas of Robert Owen. New York: International Publishers, 1962.

MORUS, Thomas. Utopia. São Paulo: LPM, 1997.

MUSSO, Pierre. Saint Simon et les saint-simoniisme. Paris: PUF, 1999.

OWEN, Robert. A new view of society and other essays. London: Penguin Books, 1991.

PETITIFILS, Jean-Christian. Os socialismos utópicos. Rio de Janeiro: Zahar, 1978. PETRE-GRENOUILLEAU, Olivier. Saint-Simon, l'utopie ou la raison en actes. Paris: Payot, 2001.

PLATÃo. A república. São Paulo: Nova Cultural, 2004.

REICH, Wilhelm. A função do orgasmo. São Paulo: Brasiliense, 1994.

SAINT-SIMON, Claude Henri de Rouvroy. Letres d'un babitant de Genève à ses contemporains. Paris: Alcan, 1925. 